\title{
THE EXCHANGES OF MINNEAPOLIS, DULUTH, KANSAS CITY, MO., OMAHA, BUFFALO, PHILADELPHIA, MILWAUKEE AND TOLEDO ${ }^{1}$
}

\section{The Minneapolis Chamber of Commerce}

Back in October, I88I, when the raising of scalps was a more popular pastime with the bulk of the inhabitants of the Northwestern prairies than the raising of crops, a handful of progressive citizens of Minneapolis got together and organized a Chamber of Commerce Association. Certificates of membership to the number of fifty, or thereabouts, were issued and Col. G. D. Rogers was elected secretary. Matters dragged along for a few years with the infant organization little better than holding its own.

The original value of the membership certificates gradually increased and the personnel of the body continued high, but there were few, if any, of the charter members who dreamed that the present powerful institution would be the outcome of the small beginning made in that early day for the city of Minneapolis. It is true that the Falls of St. Anthony were being developed for water power and a good share of that power was being used for grinding flour, but crops were meager and very faw citizens of the country had the hardihood to predict such rapid development of the Northwest as has been witnessed.

The railroads solved the problem, however, and with the rapid influx of settlers a market was needed for the products of the prairies. Minneapolis was the natural market and the soil proved adapted to wheat. Consequently, from the small beginning of the association in October, I88I, the Minneapolis Chamber of Commerce has grown to be one of the most powerful institutions of its kind in the country and the Minneapolis wheat market has grown to be the greatest primary wheat market in the world.

The real holdings of the association now represent an invest-

${ }^{1 A}$ geries of short articles reprinted in whole or in part from The National Hay and Grain Reporter's issue of May 20, 1911. These articles were specially prepared for The National Hay and Grain Reporter's number on "Grain Exchanges," and are here reproduced by special permission. 
ment of over a million dollars and its members own and control property worth many millions. In the fall of 1882 , Col. Rogers wrote an article for a leading Twin City newspaper predicting that the membership certificates, then numbering 538 , would be worth $\$ 3,000$ within twenty years. The article brought down considerable ridicule on his head, but the prediction came true nevertheless, a high water mark of $\$ 5,000$ being touched in about that time. So the Colonel, who is still actively connected with the affairs of the association as counsel, lived to laugh last. It was decided that $\mathbf{5 3 8}$ members were all that were wanted and needed and a limit was placed, but in 1900 a dozen more certificates were issued, making a total of $55^{\circ}$, where the limit has finally been fixed. These memberships are worth in the neighborhood of $\$ 4,000$ at the present writing. Of the original fifty members about ten still hold certificates, among them the Hon. J. C. Haynes, mayor of the city, who drew up the articles of incorporation for the association.

System in handling the grain was the order of the day and it was developed as fast as the trade demanded. Every effort was made to encourage agriculture and with the possible exception of one or two every year has seen an increase in the volume of grain coming into this market. Still holding the palm of being the greatest primary wheat market of the country, Minneapolis recently added the title of the greatest primary barley market of the country. Primarily, however, Minneapolis is the great milling center, made so by the unrivaled milling quality of Minnesota wheat. The malting industry is in its infancy as far as this market is concerned, but has made great strides in the past few years. The milling industry has outgrown the Falls of St. Anthony long since and steam auxiliary plants are turning most of the wheels. The latest innovation is the electric equipment recently installed by one of the largest and foremost milling companies.

The Minneapolis millers have always been in the lead as regards the correct and scientific way of making flour. Extensive laboratories are maintained by all of the leading companies and when the flour comes off the rolls the volume and quality of the same is known to a nicety. The high prices recorded in the local cash market in recent years have drawn considerable wheat from distant localities and tests are made of the different blends until the buyer on the exchange floor knows just how much of the softer 
Minnesota and Iowa wheat is needed to $\mathrm{mix}$ with the hard Northern Minnesota and Dakota wheat. A type sample is made and the season's grind is based on it as conditions and the quality of the crop change from year to year. Millers have had a leading voice in the policy of the association for years, and it is due to their aggressiveness in the flour markets of the world, to a great extent, that the local exchange has grown so in importance. They have nearly always paid the best price prevailing in the country for wheat. The biggest millers of the country are members of the local Chamber of Commerce and they control the largest mills of the world.

It would not be fit nor proper to give the millers the whole credit for the expansion of the Chamber of Commerce, however. The elevator companies whose lines reach far out into the country and bring grain into this market have a great deal to do with it. Big line elevator companies having their headquarters in Minneapolis handle the crop readily and bring a great deal of grain to this market that otherwise would find its way to competitive markets. Even though the margin of profit has been cut down and the farmers co-operative movement has made it hard sledding in late years, there are a number of powerful elevator organizations located here. In fact it is nip and tuck between the elevator and milling crowd as to which branch of the trade is of greater importance in the affairs of the association, but honors to date are about even. There is little friction between them, however, and the harmony is seldom disturbed. The terminal elevator capacity controlled by members is well over the $40,000,000$ bushel mark, or second in the country in size. A good share of this is represented by modern, up-to-date steel and concrete elevators second to none in the world. The bulk of the business is under Chamber of Commerce rules and regulations and the banks accept the warehouse receipts without question when presented as collateral.

Along with the rest of the trade the elevator operators keep abreast with the times. Through them, to a great extent, the season's requirements are learned. Their system of getting a line on the crop conditions is right up to date and when they have canvassed their agents for reports there is little use of waiting for other figures as a guide. In fact the information gathered by them is in great demand by the trade in general and many base their 
position on the market on them almost exclusively, so great is the territory the houses cover.

The commission department of the association is taken care of by an alert set of men, mostly young in years, but old in experience. To get all the traffic will bear for their customers is the consuming ambition of most of them. A good sale is a good sale, and the shipper is given all that can be gotten out of the market. Owing to the keen competition for the country trade it is probable that there is greater system here than in other lines. When a car arrives it is disposed of as promptly as the market will permit and returns made to the consignor. The great size of the freight cars nowadays and the high prices prevailing make a carload of grain quite an investment and the country dealer quite naturally wants to get his money back as quickly as possible and keep it working.

There are many cases on record where a car of wheat has been received, sold and weighed on the same day, the commission house clerk getting the weights the next morning, billing for the car and making returns to the shipper the day following. It is very ordinary for returns to be made within three or four days from the receipt of the grain. In the busy season, especially is the railroad more than willing to co-operate with the commission man and get the stuff unloaded as soon as possible and the car on its way back to the country again. The study of the needs of the situation brings a lot of grain to this market that otherwise would be diverted to other markets, as the shipper can get prompt returns, which in many cases makes up for a slight difference in prices in favor of other markets.

The understanding between the commission men and country millers, with mills within reasonable distance of Minneapolis where state weights can be obtained, also tends to aid the former in getting business away from competitive markets. Wheat arriving in the local market and sold to these millers will bring a half cent premium over the wheat sold for local delivery and weights. The country millers make it a point to handle the grain promptly and send the certificate of weights to the commission house as quickly as possible. The extra half cent more than makes up for the extra time taken for making returns to the shipper. Relations between the commission men and millers are very cordial, and few indeed are the differences that can not be settled amicably and with promptness and dispatch. 
Every facility is made use of by the buyer and seller in the cash department. The big electric quotation clock is in plain sight at all times and the latest bid or offer price in the pit is recorded instantly by the official recorder. This clock is the only one of its kind in the country, or was up to within very recently. It is the first one that could be successfully manipulated and has been the subject of much comment as well as the cause of many visits of investigation by representatives of other exchanges. It was planned by a former chief engineer of the mechanical department of the association. An accidental cutting off of the power at one time shortly after the installation made the cash wheat men doubly appreciative of the service it was performing. This clock adds a finishing touch to what is perhaps the most modern and compact trading room of any exchange in the country. The fluctuations recorded in an active market with its big red figures are rather demoralizing to a trader who is on the wrong side, more so than a few insignificant chalk figures could be. Under the clock board markers are busy chalking up the fluctuations in outside markets for the benefit of the members, some of whom need to know the value of wheat in the winter wheat markets and some who need the coarse grain quotations.

Dealing in futures was not of any importance in the local market until some time after the association was organized. In fact the commitments made were no more or less than sales and purchases to arrive within certain dates. Now, however, there are a number of big commission houses who make a specialty of looking after trades in futures for their customers. This branch of the business is as well attended to as any and the houses spare no effort to get the best they can for the people they represent. Several of them have offices through the country and in active markets do a tremendous business. In fact, when the Northwest traders get real busy they often set the pace for the rest of the world, at times when the spring wheat crop is threatened with drought or rust. The reasonable size of the pit makes quick action possible and the opportunity offered for quick trading brings in a good deal of business and the fluctuations are an influence in the markets of the world.

Recently a hedging order was cabled direct from Antwerp, for execution in the local pit. Though there may be larger markets in the country in the way of trading in futures there are none that are 
ahead of the Minneapolis market in the handling of the trades and the official checking of the records. A complete record of the transaction in the pit must be sent to the customer at the close of the session, giving the name of the buyer or seller and the time the trade is made. Every fluctuation is noted and the time at which it occurred. These figures are published in the official publication of the Chamber of Commerce, where the trader may easily verify and check any discrepancies. Then all trades are reported to the clearing house where they must check against each other. Members failing to report trades are fined and in case of error or tardiness there are fines to be met which make the careful and prompt handling of the records a matter of economy.

It is proper to mention the Chamber of Commerce Clearing House Association at this point. It is the pioneer organization of its kind in the country and for a number of years was the only one. Most of the larger firms own memberships in it and it has been found to be almost a vital necessity to the trade. Certainly it insures less friction than the old way of trading and also facilitates business generally. When the trades are checked at the close of the session the member gives a check to the clearing house for margins or in case the market has fluctuated in the favor of their customers they receive a check. It does away with a great deal of trouble. To settle with the clearing house at a certain time every day is a far different matter than calling each other for margins. Its plan of operation is practically the same as that of the clearing house of the banks and fills a need just as well. Since it has been found successful here, several other markets have adopted the plan and more are investigating it. Its management is intrusted to its originator who is undoubtedly the closest mouthed individual in the community.

Of course the information he gets in his official capacity would be of great value to traders, but a perfectly neutral attitude and a "poker face" are necessary to a man holding his position. There have been no complaints as to his qualifications to date. With the clearing house a part of the system there is no more satisfactory or reliable hedging market in the country. Under the quotation clock in big red letters is official notice to the public that the quotations are the property of the association only and bucket-shops are forbidden the use of them. There is never a relaxation of the vigi- 
lance over them where the bucket-shops are concerned and as fast as leaks have been discovered they have been closed up promptly until the operators have given up in disgust. One of the biggest bucket-shops in the country met its Waterloo when it locked horns with the Minneapolis Chamber of Commerce. Just say "bucketshop" above a whisper and there is a racket in a minute.

One of the chief objects of the Minneapolis Chamber of Commerce is to be of as great benefit to the producing and consuming ends of the grain business as possible. It would be hard to find a more progressive and liberal minded set of business men in the country or one that is more interested in the development of the section it serves, yet the grain raisers persistently misunderstand the motives and view the moves of the association with suspicion. To become a member an applicant has to undergo a rigid investigation of his previous career and must show his responsibility to look after the interest of possible customers without flunking. The application is first handed to the membership committee and when they are through investigating the matter is put up to the board of directors where it is usually passed upon and the applicant admitted to membership if the report of the membership committee is favorable. Occasionally, however, a snag is struck in one of the directors who may have some direct information of adverse nature or may not just like the report. If such is the case further investigation is made and the matter is gone over thoroughly before a certificate is transferred to the applicant. By the foregoing procedure the association keeps the morals of its body high. The shippers are insured honorable and just treatment and once admitted into the association the member is entitled to the full confidence of the trade in general.

Every care is taken to show equal justice to all in the trade and shady or questionable transactions are sure to be followed by swift and sufficient discipline. Flagrant offenses are very rare and no time is lost in purging the roll of the offending member's name. There are no memberships issued to corporations and each individual member is responsible for the actions of his firm or company.

Wheat remains the leading grain in this market, but the coarse grain trade has grown wonderfully in the last decade. If the reciprocity pact with Canada is passed there will be a great deal 
more corn and oats sown in the Northwest and further strides are looked for in that direction. The first year of the association's life about $25,000,000$ bushels of wheat were handled and about 3,000,000 bushels of coarse grain. Five years later about 40,000,000 bushels of wheat were handled and the coarse grain movement began to pick up decidedly until now the percentage of the movement is a great deal less in favor of wheat. In 1886 about a half million bushels of corn were received in this market and 155,000 bushels were shipped out. Of the Igog crop 7,021,000 bushels were received and 5,041,000 bushels shipped. Oats receipts increased from $1,877,000$ bushels to $17,610,000$ bushels in that time and barley receipts from 138,000 bushels to $22,555,000$ bushels. Rye receipts in 1886 were I I, IOo bushels as compared with $2,442,000$ bushels from the I909 crop and flax receipts were 349,000 bushels compared with 9,25I,000 bushels. The last named cereal, however, was at high tide in 1905, when 12,231,000 bushels were marketed. The notable gain was made in the barley movement, which has increased heavily every year for the last ten years.

Wheat receipts from the crop of 1885 were $32,767,000$ bushels and from the crop of 1909, IOI,567,000 bushels. Shipments from the I909 crop were $22,093,000$ bushels compared with shipments of $4,929,000$ bushels from the 1885 crop. From the 1885 crop $5,428,58$ I barrels of flour were ground and shipped while $16,919,867$ barrels of flour were ground and shipped from the 1909 crop. Last year $70,000,000$ bushels of wheat were ground into flour by the local mills, which have a capacity of I00,000,000 bushels and which the millers expect to put in full use when the Canadian pact is ratified.

The above statistics will tell the story of the growth of the Minneapolis Chamber of Commerce in plain fashion. The development of the Northwest in the cereal raising line has been phenomenal and unsurpassed and the growth has been due in some measure to the market Minneapolis offers for the products and the high comparative prices paid for the wheat crops. The association is working hand in hand with the producer and middleman in the country and with a militant arm as represented in the Minneapolis Traffic Association, in which it is a leading influence, is protecting its territory from competing markets. The old Chamber of Commerce building, which readily housed members when it was built has been succeeded by a magnificent ten story building to which an 
annex has been added to take care of the overflow of the last few years. Even at that a few big milling and elevator firms have quarters uptown because of the lack of space. The opening up of new country constantly in the Northwest and the better methods of farming in use and being encouraged will assure future growth and present indications are that the association has many years of expansion before it and a constantly growing influence in the trade of the world.

\section{The Duluth Board of Trade}

Duluth is at the head of deep water navigation on the Great Lakes, the farthest point inland that can be reached by the great carriers that have reduced transportation costs to the minimum. This commanding position makes it the great distributing center of the Northwest, and it is this that has made the Duluth Board of Trade one of the great primary markets of the United States-the third in point of total receipts, in all years of normal production in the Northwest.

The first receipts of grain at Duluth, came from the crop of I 870 and followed immediately upon the entrance of the first railroad. The great consuming markets of the East could be reached at cheapest cost by following the water route, and from the moment it became possible to make use of this highway of transportation the movement of grain turned this way and began the building of a great grain market at Duluth. As the facilities of transportation were improved and enlarged the business of the Duluth market rapidly increased, and with the great agricultural expansion of the Northwest, attained a growth that was practically without precedent in the country.

The eastern manufacturer of grain products looks to the Duluth market for his supplies of Northwestern grain. It is here that the eastern flour miller gets his supply of spring wheat; the maltster his northwestern barley; the food manufacturers and feed dealers their oats and the linseed mills their flax. The same advantages that have led to the building up of a great eastern shipping market have brought the development of a large export trade, its volume depending upon the market conditions existing in this and other countries.

When, a few years ago, the Northwest went extensively into 
the raising of flax, Duluth immediately became the leading flax market of the country, which position it still holds. Since the beginning of the production of durum wheat it has held the same position with respect to that variety of grain, and is now the only market in which contracts for future delivery in those two commodities are dealt in. In spring wheat the demands of the mills of the Northwest must naturally be first supplied, but in obtaining those supplies the northwestern miller must meet the competition of the eastern miller who is bidding at Duluth for the fine wheat of the northwestern prairies. The existence of the market at Duluth is therefore a direct and convincing benefit to the producer of the Northwest.

The Duluth market is by no means at its zenith at the present time. Its prospects for the future are as bright as its record of the past. Tremendous as are the strides made by the Northwest in agricultural development, its possibilities have been far from reached. Almost one-half of North Dakota is untouched and the same is true of South Dakota. Northern Minnesota is a great fertile region which has been suffering from an impression that it offered little hope, but there are already signs that a great tide of immigration is coming this way. Montana is fast being broken into agriculture and is a veritable empire that will soon be one of the great grain raising states of the Union.

Should Congress adopt the reciprocity agreement, the result cannot but be to add to the importance of the Duluth market. The Canadian surplus goes East via the lakes. With free trade in grain the port of Duluth will be a competitor for the traffic and the Canadian farmer will have two markets wherein to sell his products where he now has but one.

The Duluth Board of Trade as an organization has prospered. It owns a handsome seven-story building 100 by 140 feet, practically free from debt. It has two hundred memberships outstanding, all in active use. Ample elevator capacity is an essential for every primary market, and Duluth is well equipped in this respect, the capacity operated by Duluth companies aggregating $32,275,000$ bushels. Of this amount $24,500,000$ bushels is regular with its warehouse receipts deliverable on contracts. 
The Board of Trade of Kansas City, Mo.

The Board of Trade of Kansas City was organized in 1869. The grain and milling business of Kansas City is, and has been, for many years, one of its most important industries. Situated, as it is, in the center of the very best farming territory of the country, with railroad facilities unsurpassed, it naturally is a great grain receiving and distributing market, drawing from Oklahoma, Kansas, Southern Nebraska, Western Iowa and Western Missouri. It is the second largest primary wheat market and ranks third as a flour milling center in the United States. The mills, when rumning at full time, require 65,000 bushels of wheat each twenty-four hours.

The following statement of the receipts of grain shows the development of the business in this market: 1870, 1,037,000 bushels; I880, 9,029,930 bushels ; I890, 29,939,200 bushels; I900, 46,638,250 bushels; 1905, 69,599,500 bushels; I910, 50,22 I,300 bushels. These figures, however, are not a complete statement of the business done by the members of the Kansas City Board of Trade, from the fact that whenever the prices in this country are on a shipping basis with the foreign markets, large quantities of grain are bought by our members and exported direct, without passing through Kansas City and therefore do not enter into the statistical report of this board.

The handling of grain at terminal markets requires large storage capacity and these facilities must necessarily keep pace with the growth of the business. In this respect Kansas City has met the requirements of the trade, for the elevator capacity, which in I880 was I,560,000 bushels, has steadily grown and is now over I I ,000,000 bushels.

The first flour mill in Kansas City was built forty-five years ago. In the early days of milling here, only soft winter wheat was ground. Hard wheat was not known as a winter crop. This variety of wheat was introduced by the Russian Mennonites, who settled in the central part of Kansas. These people brought with them to America seed wheat of their own raising in the Crimea. At first it found no favor, but afterwards it was discovered that it closely resembled the spring wheat of Minnesota, which wheat has made Minneapolis flour famous. At first the mills ground the hard winter wheat in an experimental way, but the quality of the flour and bread produced from it quickly caused an increased 
demand, so at the present time all but the Kansas City mills grind the hard turkey wheat.

Kansas now produces an average of $80,000,000$ bushels of wheat. This, with the large yield of Oklahoma and Nebraska, insures the Kansas City mills a constant and unfailing supply. Our millers find a market in the states east of the Missouri, Cuba and Porto Rico, and have some trade with South American ports. Kansas City flour is shipped in great quantities to Great Britain, Belgium, Holland, Denmark, Scandanavia, and to some extent to Mediterranean ports.

There is large and active trading in futures on the floor of the Kansas City Board of Trade. All trades in wheat are based on No. 2 hard wheat, which is known to the trade as "contract wheat" and the wheat deliverable in contracts must be acceptable to a Board of Trade Committee, which Committee is composed of experts appointed by the president and confirmed by the directors. This gives an opportunity for millers to buy for future delivery, which they may use as a hedge or accept delivery as they may deem expedient.

This is the only market in which future trading in wheat is based exclusively on hard winter wheat.

The State of Kansas in the year I909 raised $I_{54,255,000}$ bushels of corn. While the handling of corn and other cereals in this market is of great importance, yet it is small compared with the large quantity raised in the territory tributary to Kansas City. This can be accounted for from the fact that comparatively a small percentage of the corn raised is shipped out of the state, there being an enormous and increasing demand for this cereal for cattle feeding, the farmers finding it profitable to market their corn in the form of fattened beef and pork.

The board of trade for many years has had a thoroughly well established supervising weight department which insures absolutely correct weights. It also has a sampling department which is constantly growing in favor and usefulness. Increasing purchases and sales are made, based upon the sample submitted, which sample is deposited with the chief sampler and deliveries are made under the chief sampler's supervision. His acceptance or rejection is final.

The average yield of wheat per acre in most sections of the United States is much less than in European countries and of late 
more general and active interest is being taken by agricultural colleges and economists, looking to the improvement of seed and more intensive farming. This, we believe, will result in producing a better and larger yield of cereals. In this, the Kansas City Board of Trade is deeply interested, giving it its moral and financial support. We trust that careless and indifferent farming will in the near future be a matter of history as pertaining to a people of a new country in possession of large undeveloped resources.

\section{The Kansas City Board of Trade Clearing House}

Kansas City's rise to third place among the grain future markets of the United States dates from the organization of the Board of Trade Clearing Company, in March, I899. Previous to that time the operations in deferred contracts were few and irregular, and the market had no rank as a speculative centre. As an illustration of the insignificance of the trade during the middle nineties, it may be recalled that one of the elder members of the board of trade, pointing toward the empty hexagonal pit, remarked: "That useless thing should be torn out and made into kindling wood."

But new blood was coming into the exchange, and the possibility of developing something more than a mere cash grain market was recognized. Somebody made a suggestion, and the result was the establishment of an association with the avowed purpose of facilitating the trade in futures. Kansas City being the leading winter wheat market of the country, as well as a big receiving and distributing point for corn and oats, the wonder is that traders here and throughout the Southwest had so long been content to send their hedging and speculative orders to Chicago.

The company was incorporated and capitalized at $\$ 5,000$, making the shares $\$ 50$ each. Within a year or two the success of the enterprise was assured, and in 1902 the stock issue was doubled, the IoO additional shares being sold at $\$ 175$ each, the book value at that time. Membership in the company was limited to Board of Trade members, the number of shares to be held by one person being restricted to 20. The actual number of members to-day is IIO, and the book value of shares is $\$ 350$. Annual dividends of $\$ 20$ a share have been regularly paid, although the clearing charge has been reduced from $3 \mathrm{c}$ per $\mathrm{I}, 000$ bushels to $2 \mathrm{c}$. 
Primarily the clearing house system was modeled after that of the Minneapolis Chamber of Commerce, but with the increase of business came the necessity for greater economy of time and a simplification of methods. The office work was systematized and perfected by W. L. Garrett, who was manager from May, I900, to January I, I903. It was in I90I that George G. Lee entered the service of the company as assistant manager. Under Mr. Garrett, Mr. Lee caught the spirit of the unique cancellation system, and, after further service under A. D. Wright, in 1903 and 1904, Mr. Lee was chosen as manager, with G. M. Edgecomb as assistant. The office has since remained under the control of the two men last named, and their work is highly satisfactory.

According to the statement of $\mathrm{Mr}$. Lee, the total operating expense of the clearing house is only $\$ 5,000$ a year, exclusive of telegraph charges for sending market reports to other cities. All work is done in a single room on the fifth floor of the Board of Trade building between $8 \mathrm{a} . \mathrm{m}$. and $4 \mathrm{p} . \mathrm{m}$. The rush comes with the close of the market, at $I: I_{5}$ in the afternoon, as all reports must be in by $2: 15$. On Saturday, when the market closes at noon, the balancing of accounts is done by $\mathrm{I}: 30 \mathrm{p} . \mathrm{m}$. Promptness in making returns to the clearing house is enforced by a fine of $\$ I$ when a member is 5 minutes late, and every 5 minutes of additional tardiness costs $\$ \mathrm{I}$. The fine for errors is 25 cents.

"The manager has a wide latitude in calling for margins," said $\mathrm{Mr}$. Lee. "This is necessary in cases of wild market fluctuations, or where members are suspected of financial embarrassment. As the clearing house is responsible for all trades put through it, close tab must be kept on the position of each member.

"One of the advantages of the system we use is the dispensing with the identity of the trades cleared through the house. All we know is that 'Tom' bought and sold so many thousand bushels of grain in a day, dealing with 'Dick' or 'Harry,' and that the returns of these other traders exactly correspond with 'Tom's' records. We don't know or care whether the trades were individual or for customers. That detail is a matter for the members' bookkeepers. Under the system the tying up of large sums of money in margins, in event that a long or short on the other end refuses to 'ring out,' is avoided. Thus an evil which tends to concentrate future trading into the hands of the stronger firms is eliminated. The theory is 
that the small firm has the same right as the big one to handle future business, so long as the margins tendered to the clearing house are sufficient to protect the trades involved."

So well is the Board of Trade Clearing Company's system regarded that it has recently been copied by a similar organization in the St. Louis Merchants' Exchange. Nashville traders borrowed the idea a few months ago, and the system is in use in Omaha, Wichita and New Orleans.-BY T. J. TANNER.

\section{Omaha Grain Exchange}

The nearer the point of production a market is situated, the greater the efficiency of that market, both to the producer and the consumer. This maxim has unquestionably been proven by Omaha, the youngest grain market of importance in the United States, which has risen in six years from a mere distributing point to a position among the first grain markets of the country.

From the time of the formation of the Omaha Grain Exchange to the present, the market has steadily grown in efficiency, and the skeptic who at first looked with apprehension on the exchange, has grown to respect and support it-the country shipper and outside purchaser alike attesting to its stability. Omaha is purely a primary market, and the only purely primary market of prominence in the country. Not a bushel of grain is received during the year except that which is shipped from the country stations. Fully fifty per cent of this is in turn reshipped to points other than established markets. This fact alone proves its efficiency as between the producer and consumer.

The country shipper of Nebraska, South Dakota and Western Iowa, consigning his grain to Omaha is not only assured of prompt railroad service because of the proximity of the market and thereby lessening his chances of deterioration, as in the case of corn, but this short haul greatly reduces his interest charges which are a big item during the course of a year's business. The weighing and inspection departments, which are independent and under the control of the exchange, are of the highest standard, and no better safeguards are offered in any market. The fees of this department are less than at any other large market. The reinspection rules are strictly adhered to, and the matter of discounts is left to a committee of 
unbiased members of the exchange, who determine what discounts, if any, shall be allowed, according to the values of the grain and not according to any set averages of grades. Trading among the members is broad and liberal and a more square, more aggressive association of business men cannot be found anywhere. Prices are uniformly on a parity with the other markets, and the price of oats has been higher in Omaha the past two years than at any other point. For years, it has easily maintained the proud position of Second Primary Corn Market. Omaha has started the year I9II as the fourth primary market of the United States.

Previous to the organization of the exchange, the elevator capacity was 2,140,000 bushels and the receipts for 1904, which was the first year of the existence of the exchange, were less than 18 ,000,000 bushels, of which approximately 4,000,000 bushels were wheat; 9,000,000 bushels corn and 4,050,000 bushels oats. Compared with this, the market received 24,000,000 bushels of corn alone last year, being the second primary corn market of the country. Receipts for the last two or three years have been about $43,000,000$ or 44,000,000 bushels, or two and one-half times as great as for the first year of the life of the market. The elevator capacity has almost trebled, being now 6, I I 5,000 bushels.

Though total grain receipts for last year varied but slightly from the previous year, Omaha gained over 3,000,000 bushels in corn receipts, growing to greater importance than ever before as a primary corn market. It is not strange, though, that corn receipts are large, or that it is expected that they will be still larger in coming years, as Omaha is a natural market for two great corn states, Nebraska and lowa.

When the exchange was started, it was with a limited number of "smaller dealers ;" the line companies had practically all the business. Now thirty-eight active grain firms hold membership in the exchange, with ninety-two active grain members. And at the same time the line companies are doing more business than ever before. The market has broadened. A large percentage of the membership does a consignment business and the market is broad enough now so that any commission merchant can always find an outlet for his patron's grain at attractive figures. More actual transactions have been made on the exchange floor within the last year than in any other year in the exchange's history. The records of Chief Grain 
Inspector Powell show that more grain, by 25 per cent, was weighed and inspected in Omaha in I9IO than in any other previous year.F. P. Manchester, Secretary.

\section{The Buffalo Corn Exchange}

The grain trade of Buffalo prior to 1906 was associated with the Chamber of Commerce, which was the general commercial organization of the city, representing as it did all branches of local industry. For a long period previous to this the Buffalo grain merchants enthused with a growing pride in their city and realizing the magnitude of the grain business which it enjoyed, determined that Buffalo, like all other large grain centers, should support an exclusive grain organization. Consequent upon this universal desire to boost the commercial interests of the great city of Buffalo and to unite all the representative grain interests of this port under an exclusive association, the Corn Exchange of Buffalo was organized and commenced active operations in April, I9o6. At this time the departments of inspection and weighing of grain were assumed by the corn exchange and entire jurisdiction over all matters pertaining to the grain trade were taken by the newly organized body.

At the outset, the corn exchange enjoyed the confidence and respect of her sister grain exchanges and was abundantly supported by the grain trade at large. The Buffalo grain interests teeming with pride in the success of their efforts, have perfected an organization representing an exclusive cash grain market, unsurpassed in the United States. The success of the grain business in this city is evidenced by an increase in the annual working force in the inspection and weighing department of from seven employees in I 898 to thirty-two in I9I I.

Buffalo is especially favored as a grain center, it being an undisputed fact that it is the greatest as well as the most available distributing point in the United States, due to the exceptional geographical position which it enjoys and the transportation facilities it possesses, both rail and water. The city located as it is at the foot of the Great Lakes is a magnet between the grain shipping interests of the West and the Northwest and the Atlantic seaboard, being accessible by numerous trunk line railroads of which Buffalo is the terminus. Upwards of fifteen railroads enter the city, rendering the most complete facilities for handling the grain product of 
the West and distributing same throughout the East and South. The elevator facilities are unexcelled with a capacity of upwards of $22,000,000$ bushels, and at an approximate cost of $\$ 14,000,000$. This elevator capacity for receiving grain from lake vessels and railroads and transferring same to canal boats and cars makes a possible transfer capacity each twenty-four hours of 5,500,000 bushels. Also the malting interests of this city represent a total storage capacity of II,550,000 bushels with an estimated capital of $\$ 6,000,000$.

The large transfer elevator capacity and facilities for handling grain, afford a great protection to shippers, especially of corn, which at certain seasons of the year is susceptible to rapid changes in condition. Such grain is cooled, dried and put into merchantable condition for a reasonable charge, thus placing the Buffalo market in an enviable position for the disposal of soft corn, and any other grain which is out of condition. This is partially evidenced by a comparison of the receipts of corn in I9Io of about $37,793,368$ bushels as against $31,478,578$ bushels in 1909 .

Buffalo is also listed among the first cities of the United States for its flour milling industry, which showed an output in I9Io of 4,095,650 barrels, an increase of 695,000 barrels over 1909. During the year IgO9 and I9Io the milling industry has been greatly improved and the output increased 8,000 barrels daily, with a total daily output of 20,000 barrels, making it the second milling city in the world.

Taking a resumé of Buffalo's superior advantages as a grain market, it occupies a position unexcelled in this country, which is evidenced by its excellent geographical position, its elevator equipment, its lake and rail facilities for receiving, handling and distributing grain and grain products, and the protection afforded the grain trade through the organization of the corn exchange, which it is the duty and privilege of this and all other grain exchanges to provide.-FRED B. POND, Secretary.

\section{The Commercial Exchange of Philadelphia}

After a successful history of fifty-seven years, keeping in close touch with the domestic and export grain trade of the United States and the exact situation in other countries, and always in the 
lead for the greatest advantages of its terminal port, the improvement of the water rail facilities, and the most equitable rates and regulations for traffic, the highest standard inspections of all manner of grains, as well as flour, feeds, hay and straw, together with provisions, the members of the commercial exchange can look back through the dim vista of the past with the greatest pride on the many substantial accomplishments brought about for the advantage of the growing business interests of Philadelphia and the Keystone State, with its busy neighbors, almost entirely through the efforts of this prominent and influential trade organization.

Like many leading commercial associations of the present day, its beginning was of the humblest character, but "great oaks from little acorns grow." For, in the year I854 a modest coterie of flour and grain men assembled in a small room on the second floor at Second and Gold streets, and after some interchange of opinions, they decided to form a business association, and a tentative constitution and by-laws were adopted. At the next meeting a ponderous leather-bound book was presented, still in the possession of the exchange, in which the first minutes were recorded, and the signatures of the men who were the leaders in this movement are therein contained, as legible as on the day when they were written, and it may be of some interest to note that the penmanship of those times was exceedingly ornate, inasmuch as the signatures of the most conservative of the merchants are replete with really graceful flourishes.

William B. Thomas, the father-in-law of Hunter Brooke, the present head of the well-known malt and grain firm, first a colonel, then a general in the Federal Army, and afterwards Collector of the Port of Philadelphia, presided at these early meetings, and was chosen chairman of the committee to draft the constitution and was installed the first president of the then known Corn Exchange Association; Samuel L. Witmer was made secretary.

For a time the preliminary organization became known as "The Flour and Grain Exchange Association," for it was then simply a combination for the furthering of the retail trade, and many of the great tracts of land which since have made wheat history for the world, were then only known as virgin soil. The telegraph had just rounded its first decade, and the inter-continental cable had not been laid. In those days the grain trade in general had 
the romance of uncertainty, and modern speculating in grain is like betting on a sure thing as compared to the reckless way in which Dame Fortune was wooed when the exchange was in its infancy.

For example, a ship would leave this port and put out to sea laden with grain. The consignor did not know what he would get for the cargo. The trip might be an entire loss, or perhaps a snug little fortune was realized. Often times there would be a rumor in this country that there was a famine in Ireland, and as it took a sailing vessel at least two months to make the voyage across the ocean, the distress could be relieved before the ship reached Liverpool.

The skippers of the grain ships were mainly of that sturdy, resourceful type who would frequently be entrusted with selling the grain when the coast of England was reached. If the captain of the craft was not accorded this responsibility, a young man from the broker's office, or a member of the firm listed as a "supercargo" would make the voyage. As sixty days was the average time to sail across the ocean, it was usually an additional month before the consignor could learn what had been the fate of the cargo. During those long, long waits the merchant of Philadelphia controlled his nerves as best he could, haunting the ship offices to glean the thirty-day-old gossip.

But if the news at last proved favorable the profits were often large and the financial harvest added an encouraging zest of adventure to the next cargo which was sent out from the port. But things are different now, for that was over half a century ago. Now the grain and flour, feed and hay are bought in the West and elsewhere by wire, and if the grain goes to England, it is sold by cablegram, and the transportation is frequently arranged by telephone. The shipper knows just how the market stands at every point in the civilized world, and through the up-to-date business progression, the old-time romance of wheat and corn exporting has been completely wiped out of existence.

The initial meetings of the exchange were held at Second and Gold streets, but as the association became strong in membership and influence, a building of its own was erected on the east side of Second street, between Walnut and Chestnut, which was styled the Chamber of Commerce, and was pointed out as the headquarters 
of the grain trade to business strangers coming to the city. The exchange occupied the second floor, with offices below, the structure being on the historic ground of the old "Slate Roof" house of William Penn, and when the "Corn Exchange" proposed to build, and William Welsh, at the head of a committee of citizens, secured the property, the Quaker element was shocked as they maintained that a priceless relic was sacrificed. When it was proposed to purchase as far south as Walnut street, the discovery was made that a small portion of land, twelve by sixteen feet, was not covered by original deeds or patents. This proved to belong to the Six Nations, to which it had been presented by the sons of William Penn, when the Indian Chiefs, on a visit to Philadelphia, refused to negotiate a treaty or even talk about it, until they could stand on their own ground and build a council fire on their own land. One of the committee visited the Indian Reservation on the Allegheny River, and was referred to "Colonel Parker," their chief in New York. He confirmed the fact, but said there was no record, a wampum belt having been the confirmation. This belt has since been deposited at Albany, with all the wampum belts of the Six Nations, and said to have been destroyed by the recent fire at the Capitol buildings. Granville Penn visited this plot of ground and knew all about it. The exact location is in the rear of 45 South Second street. The dedication of this new home took place on March I, I869, just a year following the change of the name of the organization from the Corn Exchange Association to the Commercial Exchange of Philadelphia, and after an occupancy of nine months a disastrous fire broke out and the building was burned to the ground, the entire fire department of the city failing in their endeavor to save the structure which was of brick.

The next great chapter in the history of the exchange was the movement which brought about the establishment of the American Line of steamships making quick communications between this port and Great Britain; then came the stubborn but successful contest with New York to retain the ruling differentials here, which was a long-drawn period of trade warfare. Before the war Philadelphia had an extensive trade with the southern states, and after peace was declared the main source of supply was in Pennsylvania, Ohio, Southern Delaware and Maryland. This condition, however, was changed by the outreaching of the western trunk lines when the 
great wheat and corn belts, west and northwest of the Missouri River, were thrown open.

Thirty or forty years ago 20,000 pounds was considered a maximum freight car load, and all above that was charged as excess freight; now the maximum is easily 100,000 pounds.

In I854 the grain firm that had a correspondent one hundred and fifty miles away within the country was considered unusually progressive, while now the members deal two thousand miles inland and three thousand miles over the water. With the development of the industry came a change in the class of memberships, which in the beginning covered miscellaneous business. Coal dealers, liquor men, grocers and dry goods merchants have dropped out and those principally interested in cereals are mainly in evidence now. The membership is comprised largely of those handling flour, feeds, grain, hay, straw and provisions, though leading representatives of the banks, railroads, shipping lines, distillers and brewers are still on the roll.

In 1894-5, when the "Bourse" was completed with its mammoth building which extends from Fourth to Fifth streets the length of an entire square, and modeled after its foreign namesake, the only establishment of its kind in the United States, the Commercial Exchange disposed of its stock holdings in the Chamber of Commerce building, and, under President E. L. Rogers, made a lease for their present quarters on the north side of the main floor of the Bourse which they now occupy; and, while for a time some of the veterans in the grain trade looked upon the move of abandoning their old home for a modern leasehold, as an unfortunate move and loss of identity, the great advantages derived in the accommodations and facilities, including telegraphs, tickers, quotation boards, long and short distance telephones, office, floor and sample table space, postoffice, reading, writing and news rooms, with dining restaurant and every known up-to-date equipment and privilege, they have become fully reconciled to its untold improvements and comforts.

The grain inspection department for twenty-five years in special personal charge of Captain John O. Foering, who received all inspection dues and paid his corps of assistants, bringing the character of inspections at this port up to the highest standard, has now become a fixed department and asset of the exchange, whose chief official is William J. Duffy, who occupies a special room in the Bourse building with his deputies. 
While the exchange is one of the oldest trade bodies in the country, from time to time at the closing of each year it has thrown its dignity to the winds and lined up the grain men against the flour men in a pitched battle over the grain floor, after call hours, pelting each other most mercilessly with sample bags of grain and flour until one side gained the victory. But reform and progressiveness became popular a year ago, and this ancient but strenuous custom has been consigned to the tombs of the Capulets, and music and song and good fellowship now usher out the old year.

In the early days the annual elections were most expensive and exciting, champagne flowed like water and "green wads" changed a plenty, and cabs and carriages gave free rides to voters from every section of the city. Now, with an occasional exception, this annual affair, which closes with a luncheon, is a veritable "love feast."

Exports of corn in 1900 footed up $33,45^{2}, 170$ bushels, and in I908 there was shipped abroad 17,061,938 bushels of wheat, and in I899 the export oats total footed up $7,880,766$ bushels; but since Russia and the Argentines have gone into sharp competition for the European balance grain trade, exports here as well as elsewhere have fallen off considerably.

\section{The Milwaukee Chamber of Commerce}

The Milwaukee Chamber of Commerce is one of the oldest exchanges of the West or middle West, and Milwaukee, at one time, as we are fond of recalling, was probably the principal primary market of the country. That proud distinction cannot be claimed for her now, under the changed conditions of transportation, the shifting of population centers and the development of new territory, but Milwaukee, nevertheless, lays rightful claim to many advantages as a market for grain that will ever keep her in the front rank, and there will be in the future an organized and systematic influence at work to keep these advantages and the superior facilities existing in this market, before the eyes of the rest of the world.

Considering Milwaukee as a market to which the shipper may profitably consign his grain, hay and seeds, we are proud of our weighing and inspection departments, and are gratified to know that Milwaukee weights have an enviable reputation for reliability among the trade, as has so often been testified to.

Milwaukee is one of the very few large markets of the country 
where the inspection of grain is not under the control of the state. The inspection here is under the supervision of the Milwaukee Chamber of Commerce, and in the fifty odd years that this has been so, no occasion has arisen for placing the inspection of grain in any other hands than those of the chamber of commerce. The department is constantly striving to improve methods and increase efficiency, until there has been evolved an almost perfect piece of mechanism which serves the association of six hundred members, composed of all the varied interests, receiving, shipping, milling, malting, etc., with equal justice and fairness to all.

The improved methods adopted for the sampling and inspection of grain have been the means, during the past year, of attracting buyers to this market, where the grades of grain can be fully relied upon, comparing favorably in this respect with any other market.

\section{Milwanke as a Market}

Milwaukee furnishes an excellent market for wheat and all the coarse grains. Mills and malting establishments require wheat and barley for manufacturing purposes, and during I9Io approximately $6,000,000$ bushels of wheat and I $1,000,000$ bushels of barley went into local consumption for the manufacture of flour and malt, respectively.

The total receipts of all kinds of grain at Milwaukee during I9Io were $48,355,9 I_{4}$ bushels, with two exceptions, viz.: I 898 and I899, the largest in any year in the history of the city.

Corn and oats are handled extensively here, and a large trade exists with Eastern territory in these grains. An exceptionally good outlet to the East is found in the transit lines across Lake Michigan to Grand Haven and Ludington. Car-ferry and break bulk service in connection with the Pere Marquette and Grand Trunk Railways, is maintained throughout the entire year. The eastern buyer is enabled to receive an official certificate which shows him that the weight of grain being transferred through the elevator of the railroad company on the east shore of Lake Michigan, has been determined under the supervision of a sworn weigher of the Milwaukee Chamber of Commerce.

There is no market more favorably situated than Milwaukee, so far as the cost of freight transportation is concerned, and shippers are given the benefit of the lowest freight rates in having their 
grain ultimately placed with the dealer, manufacturer or consumer, either in the western or eastern market.

The railway companies, during the past year, have greatly increased the terminal facilities at Milwaukee, and grain shipments are given preference over nearly all other kinds of freight. Switching arrangements, both locally and to connecting lines, are now perfect and at the least expense to the shippers.

Much has been recently said and written regarding "privilege trading," a form of contract which is used in most all markets, but with certain restrictions or modifications in some.

Trading in privileges is one of the features in this market. It has never been regarded as illegal in Wisconsin, as it has been declared in some other states. In fact, a Wisconsin law of the 1902-03 session asserts:

"That in every purchase or sale, or purchase and sale, and all other transactions by or between members of any lawfully constituted chamber of commerce or board of trade organized under or by virtue of the laws of this state, and in accordance with the charter of such corporation, and the rules, by-laws and resolutions adopted therein, shall be prima facie valid."-H. A. Plumb, Secretary.

\section{The Toledo Produce Exchange}

With its splendid location and almost unrivaled transportation facilities, Toledo stands well to the front among the terminal grain markets of the country. The city can look backward to a glorious past in the annals of grain history, but what is more important, the market is flourishing lustily at present and gives promise of continued growth and development. Reasons why the city at the mouth of the Maumee always has been a big grain center are not hard to find. Twenty-one steam railways draining one of the most fertile agricultural sections on the face of the globe make it the fourth railroad center in the country. Another powerful factor is the magnificent harbor, on whose ample bosom could snugly nestle all the craft on the great lakes without any crowding. There are practically fifteen miles of water deep enough for vessels of maximum draught.

In a number of important particulars, Toledo is really a world's power. It is the center for the milling of soft winter wheat flour, 
and leads in this type of grain. As the leading clover seed market, Toledo gets recognition abroad as well as at home.

In the matter of elevators, Toledo is splendidly fortified. While the gross capacity is somewhat less than in former days when wooden houses predominated, the fact that practically all are of modern fireproof construction, shows the storage proposition in a better light. The general impression is that the day of the dangerous frame structure has neared the end. It is a matter of interest that in Toledo, the first iron tank for grain was built. This was in I894. Recently, concrete has been used with such success that more elevators will be built of this material. To Toledo belongs the credit of successfully experimenting with the movable marine leg for handling cereals and flaxseed.

Toledo is destined to broaden out from practically a strictly winter wheat milling center to a distributing point for spring wheat. Flour men, realizing the advantage of Toledo as a strategic point, are pulling together as never before in an effort to get the market all it deserves in the way of freight rates and other things. Most local mills are realizing the importance of spring and winter wheat blend flours and the demand for local use and shipment to interior points continues to enlarge.

Besides giving Toledo first rank in the world as a market, the trade in field seeds helps the grain business materially. There is a reason why the city plays the leading role in clover seed. Toledo is located in the center of the richest clover territory in the country, the productiveness, it is believed being the result of moisture carried by winds from the great lakes. The local seed market is notable for its exclusive system of trading in futures. In no other market are there transactions in clover futures. 